\title{
Discussion on Calculation Method of Shear Bearing Capacity of HSC Beams Without Web Reinforcement under Concentrated Loads
}

\author{
Qingfu $\mathrm{Li}^{1} *$, Huade $\mathrm{Zhou}^{1}$ \\ ${ }^{1}$ School of Water Conservancy Engineering, Zhengzhou University, Zhengzhou, China
}

\begin{abstract}
In order to investigate the main influencing factors and development rules of the shear performance of high strength concrete (HSC) beams without web reinforcement under concentrated loads, analyze and compare the rationality of the China and American Code formulas and Zsutty formula, in this paper, 303 sets of experimental data about the shear test of HSC beams without web reinforcement at home and abroad were selected, based on these experimental data, the calculation method of the shear capacity of HSC beams without web reinforcement was discussed. The results showed that the measured shear bearing capacity of HSC beams without web reinforcement gradually increases with the decrease of the shear-span ratio. The nominal shear stress of HSC beams without web reinforcement gradually increases with the increase of concrete strength, the increase of longitudinal reinforcement ratio and the decrease of section height. The shear bearing capacity formula proposed by Zsutty is the most accurate prediction than other formulas. Based on the experimental data and considering the influence of the longitudinal reinforcement ratio on the shear bearing capacity of structure, a new calculation formula for the shear bearing capacity of HSC beams without web reinforcement under concentrated loads was obtained by regression analyze, and this formula is more comprehensive than the other three calculation formulas, moreover, the calculation results are more reasonable.
\end{abstract}

\section{Introduction}

It is well known that ordinary concrete has low compressive strength and weak impact resistance, which is often difficult to meet people's design and construction needs when constructing high-rise and super high-rise buildings. HSC has the characteristics of high compressive strength, impact resistance, excellent durability performance, etc. The use of HSC can reduce the cross-sectional size of structure, and effectively reduce the weight of the structure itself, improve the structural load-bearing capacity, and has good durability 1, which has been widely used in the design and construction process of high-rise and super high-rise buildings. As the most basic structural load-bearing member, the flexural and shear bearing capacity of beams are crucial to the safe use of the structure.

A large number of studies have been conducted on the shear bearing capacity of HSC beams without web reinforcement at home and abroad, and certain results have been obtained. Among them, Bukhar 2 conducted shear tests on 27 pieces of HSC without web reinforcement, and investigated the effect of shear-span ratio, concrete strength, and longitudinal reinforcement ratio on the shear bearing capacity, and found that the shear strength and damage mode depends on the shearspan ratio and longitudinal reinforcement ratio. Cladera 3 studied the shear failure response of HSC beams with or without web reinforcement and found that beams without web reinforcement showed very brittle properties and the higher the compressive strength of concrete, the more serious their damage. Ahmed 4 and Elzanaty 5 respectively conducted shear tests on HSC beams without web reinforcement and reached a consistent conclusion that ACI 318 Code is not conservative for calculating the shear bearing capacity of HSC beams with low reinforcement ratio. Yu 6 designed and produced 6 pieces of HSC beams without web reinforcement, and studied their shear bearing capacity under concentrated loads, and the results show that under the same concrete strength conditions, the measured shear bearing capacity of the beams increased significantly with the decrease of the shear-span ratio, and the shear bearing capacity of different structure increased with the increase of concrete strength when shear damage occurred. Zhi et all. 7 tested the shear strength of 9 pieces of ultra-high-strength concrete beams without web reinforcement under concentrated loads and found that the shear failure mode of ultra-high-strength concrete is not much different from ordinary concrete, and the shear failure mode is brittle failure, and based on the experimental results, a regression formula for the shear strength of ultra-high-strength concrete beams without web reinforcement under concentrated loads is proposed. At present, although many studies have been carried out on the mechanical

*Corresponding author's e-mail: lqflch@zzu.edu.cn 
performance of HSC beams at home and abroad, due to the different focuses of the researchers and the different numbers of experiments, the rules obtained are also different, and it is difficult to generalize with a certain formula. Moreover, many domestic and foreign code formulas are based on the test of ordinary concrete beams, and whether they can be applied to the shear design of HSC beams needs further examination. Based on this, this paper analyzes the effects of shear-span ratio, concrete strength, longitudinal reinforcement ratio and crosssectional dimensions on the shear performance of HSC beams without webs based on the collected experimental data of 303 groups of HSC beams without web reinforcement at home and abroad, and compares them with the shear bearing capacity formula of concrete beams proposed by China's Code for Design of Concrete Structures (GB 50010-2010), American Code for Design of Concrete Structures (ACI 318-14) and Zsutty, the calculation formula of shear bearing capacity of beams without web reinforcement considering shear-span ratio, concrete strength and longitudinal reinforcement ratio is put forward. Compared with the experimental data, the formula presented in this paper has a better applicability.

\section{Source of experimental data}

This paper collects the experimental data of HSC beams without web reinforcement listed in domestic and foreign literature, and the cross-sectional shape of the beams are rectangular and bears concentrated loads. The American, Japan, and the European Concrete Association all use the compressive strength of standard cylinder specimens as the index of axial compressive strength. For the conversion relationship between the concrete cube compressive strength $f_{c u}$ and the cylinder compressive strength $f_{c}{ }^{\prime}$, the $f_{c}{ }^{\prime}=0.85 f_{c u}$ proposed by Ye 8 was used. In the process of converting the tensile strength of concrete $f_{t}$ and cube compressive strength $f_{c u}, \mathrm{Wu}$ 9 pointed out that the difference between the working conditions of concrete in the structure and the working conditions of the specimens should be considered, and multiplied by a correction coefficient of 0.88 on the basis of the specification, in order to facilitate the comparison of the parameters, a unified conversion is carried out, and the formula is:

$$
f_{t}=0.88 \times 0.395 \times f_{c u}^{0.55}
$$

Where, $f_{t}$ is the axial tensile strength of concrete, $\mathrm{MPa} ; f_{c u}$ is the compressive strength of concrete cube with side length of $150 \mathrm{~mm}, \mathrm{MPa}$.

After screening and conversion, a total of 303 groups experimental data of HSC beams without web reinforcement were collected from the literature 2 , as shown in Table 1.

Table1. Experimental data of shear bearing capacity of HSC beams without web reinforcement

\begin{tabular}{|c|c|c|c|c|c|c|c|c|}
\hline Author & $\mathrm{N}$ & $\lambda$ & $b / \mathrm{mm}$ & $h o / \mathrm{mm}$ & $f_{t} / \mathrm{MPa}$ & $f_{c}^{\prime} / \mathrm{MPa}$ & $\rho_{/ \%}$ & $V_{u} / \mathrm{kN}$ \\
\hline $\mathrm{Yu}$ & 6 & $1 \sim 3$ & $196 \sim 204$ & $400 \sim 418$ & $4.21 \sim 4.43$ & $79.3 \sim 86.96$ & 1.13 & $80 \sim 615$ \\
\hline $\mathrm{Li}$ & 9 & $0.94 \sim 2.89$ & $149 \sim 162$ & $259 \sim 271$ & $4.24 \sim 4.62$ & $80.35 \sim 93.63$ & $3.92 \sim 5.32$ & $61.95 \sim 768.2$ \\
\hline Wang & 11 & $2 \sim 4$ & 200 & $150 \sim 600$ & $3.83 \sim 5.01$ & $66.8 \sim 108.72$ & 1.23 & $159.8 \sim 875.2$ \\
\hline $\mathrm{Lu}$ & 3 & $3.03 \sim 3.04$ & 200 & $362 \sim 363$ & $2.77 \sim 3.47$ & $47.48 \sim 66.5$ & 2.03 & $110.19 \sim 123.06$ \\
\hline Zhao & 25 & $1 \sim 4$ & $150 \sim 154$ & $260 \sim 267$ & $3.67 \sim 4.2$ & $61.8 \sim 78.93$ & $1.65 \sim 3.42$ & $63 \sim 257.36$ \\
\hline Pan & 4 & $1.5 \sim 2.2$ & 200 & 365 & $3 \sim 3.7$ & $51 \sim 62.65$ & 2.03 & $260.76 \sim 422.71$ \\
\hline Keun & 10 & $0.53 \sim 1.13$ & 160 & $355 \sim 935$ & 4.19 & 78.5 & $0.98 \sim 1$ & $338.1 \sim 1029$ \\
\hline Imran & 27 & $2 \sim 6$ & 152.4 & 266.7 & $3.08 \sim 3.37$ & $44.77 \sim 52.77$ & $0.58 \sim 1.07$ & $6.21 \sim 26.13$ \\
\hline Islam & 15 & $2 \sim 4$ & 150 & $203 \sim 207$ & $3.33 \sim 4.33$ & $50.8 \sim 83.3$ & $2 \sim 3.2$ & $45.5 \sim 131.1$ \\
\hline cladera & 6 & 3.01 & 200 & 359 & $3.26 \sim 4.43$ & $49.9 \sim 87$ & 2.24 & $99.69 \sim 140.09$ \\
\hline Zhang & 3 & 2 & 250 & 409 & 3.95 & 70.65 & $0.6 \sim 1.75$ & $247 \sim 574.9$ \\
\hline Ahamad & 3 & $1 \sim 3$ & 127 & 215.9 & $4.01 \sim 4.11$ & $72.62 \sim 75.78$ & 2.07 & $101.44 \sim 105.84$ \\
\hline thorenfel & 16 & $3 \sim 4$ & $150 \sim 300$ & $207 \sim 442$ & $3.3 \sim 4.58$ & $51 \sim 92.31$ & $1.82 \sim 3.24$ & $56 \sim 281$ \\
\hline Scholz & 3 & $3 \sim 4$ & 200 & $362 \sim 372$ & $4.13 \sim 4.56$ & $76.5 \sim 91.63$ & $0.81 \sim 1.94$ & $83 \sim 121$ \\
\hline Remmel & 4 & $3.06 \sim 4$ & 150 & $160 \sim 165$ & $4.23 \sim 4.24$ & $79.82 \sim 80.41$ & $1.87 \sim 4.09$ & $46 \sim 60$ \\
\hline hallgren & 16 & $2.61 \sim 3.65$ & $150 \sim 337$ & $192 \sim 211$ & $3.77 \sim 4.55$ & $61.63 \sim 90.35$ & $0.57 \sim 4.1$ & $69 \sim 104$ \\
\hline Elzanaty & 6 & $4 \sim 6$ & 178 & $267 \sim 270$ & $3.61 \sim 4.08$ & $59.84 \sim 74.88$ & $1.19 \sim 3.21$ & $57 \sim 75$ \\
\hline Ahmad & 16 & $2.7 \sim 4$ & 127 & $184 \sim 208$ & $3.58 \sim 3.77$ & $58.9 \sim 64.85$ & $1.77 \sim 6.64$ & $44 \sim 100$ \\
\hline crimm & 12 & $3.53 \sim 3.9$ & 300 & $146 \sim 746$ & $4.38 \sim 4.91$ & $85.1 \sim 104.72$ & $0.83 \sim 4.22$ & $70 \sim 379$ \\
\hline Mphonde & 8 & $2.41 \sim 3.49$ & 152 & 298 & $3.85 \sim 4.54$ & $67.24 \sim 90.78$ & 3.34 & $89 \sim 206$ \\
\hline Islam & 8 & $2.96 \sim 3.94$ & 150 & 203 & $3.88 \sim 4.19$ & $68.17 \sim 78.71$ & 3.22 & $58 \sim 117$ \\
\hline Podgomia & 3 & $2.88 \sim 2.92$ & 300 & $450 \sim 925$ & $4.48 \sim 4.61$ & $88.74 \sim 93.5$ & $0.5 \sim 0.81$ & $132 \sim 193$ \\
\hline Hanson & 2 & 2.48 & 152 & 267 & $3.44 \sim 3.92$ & $54.74 \sim 69.62$ & 4.99 & $127 \sim 165$ \\
\hline Yoon & 2 & 3.28 & 375 & 655 & $3.84 \sim 4.43$ & $67 \sim 87$ & 2.85 & $296 \sim 327$ \\
\hline M Suzuki & 48 & $2 \sim 4$ & 200 & $150 \sim 160$ & $3.95 \sim 5.42$ & $70.7 \sim 680.2$ & $0.85 \sim 2.17$ & $76.4 \sim 680.2$ \\
\hline Collins & 1 & 2.92 & 300 & 925 & 4.59 & 92.57 & 1.01 & 193 \\
\hline $\mathrm{Xie}$ & 1 & 3 & 127 & 216 & 4.66 & 95.29 & 2.07 & 46 \\
\hline Adebar & 1 & 2.88 & 290 & 278 & 3.46 & 55.79 & 0.99 & 90 \\
\hline Jin & 1 & 2.25 & 150 & 200 & 5.15 & 114.41 & 8.18 & 450.5 \\
\hline Wang & 13 & $2 \sim 4$ & 200 & 350 & $4.09 \sim 5.61$ & $75.1 \sim 133.37$ & 1.23 & $79.9 \sim 263.1$ \\
\hline M.Hamrt & 8 & $1 \sim 3$ & 100 & $133 \sim 135$ & 4.39 & 85.5 & $1.16 \sim 2.31$ & $50.7 \sim 224$ \\
\hline Kolhapure & 4 & $2.5 \sim 3.25$ & 125 & $100 \sim 130$ & 3.87 & 68 & $1.8 \sim 3.2$ & $64 \sim 80$ \\
\hline Wassim & 6 & 2.5 & 400 & $65 \sim 889$ & 3.56 & 58.55 & 2 & $76 \sim 311.4$ \\
\hline Angelakos & 2 & 2.92 & 300 & 925 & $3.66 \sim 4.1$ & $61.37 \sim 75.57$ & 1.01 & $172 \sim 185$ \\
\hline
\end{tabular}

Note: $\lambda$ is the calculated section shear-span ratio; $b$ is the calculated section width; $h_{0}$ is the effective height of the calculated section; $f_{t}$ is the design value of the concrete axial tensile strength; $f_{c}^{\prime}$ is the compressive strength of the concrete cylinder; $\rho$ is the longitudinal reinforcement ratio; $V_{u}$ is the measured shear bearing capacity of the specimen. 


\section{Comparison of calculation formulas}

\subsection{China Code (GB 50010-2010)}

The formula for the shear bearing capacity of beams without web reinforcement under concentrated loads in the China Code for Design of Concrete Structures (GB 50010-2010) 23 (hereinafter referred to as the China Code) is based on statistics of experimental data, and the formula is:

$$
V \leq V_{C S}=\frac{1.75}{\lambda+1} f_{t} b h_{0}
$$

Where, $\lambda$ is the shear-span ratio, when $\lambda<1.5$, take 1.5 , when $\lambda>3$, take $3 ; f_{t}$ is the axial tensile strength of concrete; $b$ is the calculated section width; $h_{0}$ is the effective height of the calculated section.

\subsection{American Code (ACI 318-14)}

The calculation formula for calculating the shear bearing capacity $V_{c}$ of beams without web reinforcement in the American Code for Design of Concrete Structures ACI 318-14 24 (hereinafter referred to as the American Code) is:

$$
V_{C}=\left(0.16 \lambda \sqrt{f^{\prime}{ }_{c}}+17 \rho_{w} \frac{V_{u} d}{M_{u}}\right) b_{w} d \leq 0.29 \lambda \sqrt{f^{\prime}{ }_{c}} b_{w} d
$$

Where, $f_{c}^{\prime}$ is the compressive strength of concrete cylinder; $M_{u} 、 V_{u}$ are the bending moment and shear force of the calculated section; $\lambda$ is the correction coefficient of the concrete material, generally taken as 1 for concrete,

Table2. Related parameters of the ratio of bea

\begin{tabular}{cccccc}
\hline $\begin{array}{c}\text { Number of test data } \\
\text { (N) }\end{array}$ & $\begin{array}{c}\text { Formula } \\
\text { category }\end{array}$ & $\begin{array}{c}\text { Average } \\
\text { value }\end{array}$ & Variance & $\begin{array}{c}\text { Standard } \\
\text { deviation }\end{array}$ & $\begin{array}{c}\text { Coefficient of } \\
\text { variation }\end{array}$ \\
\hline 303 & GB 50010-2010 & 1.551 & 0.88 & 0.94 & 0.61 \\
303 & Zsutty & 1.547 & 0.8 & 0.89 & 0.58 \\
303 & ACI 318 -14 & 2.109 & 2.33 & 1.53 & 0.73 \\
\hline
\end{tabular}

By observing Table 2, it can be seen that no matter which shear bearing capacity calculation formula is used, the shear bearing capacity experimental value is greater than the theoretical calculation value, and all have sufficient safety reserve, but the safety reserve of the American code is too conservative, and the China Code and Zsutty formula are relatively more reasonable, and the degree of discrete of data is smaller than the American Code. The result of Reddy 26 also show that Zsutty formula is more accurate to calculate the shear bearing capacity of HSC without web reinforcement.

\section{The main influencing factors of shear performance}

\subsection{Influence of shear-span ratio}

0.75 for light-weight concrete, and 0.85 for partial lightweight concrete; $b_{w}$ is the width of the calculated section;

$d$ is the effective height of the calculated section; $\rho_{w}$ is the ratio of longitudinal reinforcement.

\subsection{Zsutty formula}

In 1968, scholar Zsutty 25 gave formulas for shear bearing capacity based on experimental data through statistical analysis, which are mainly took concrete strength, shearspan ratio, and longitudinal reinforcement ratio as the main variables. The formulas are:

$$
V=2.2 \times \sqrt[3]{f^{\prime}{ }_{c} \rho \frac{d}{a}} \times \mathrm{b} \times d \quad \lambda \geq 2.5
$$

$V=\left(2.5 \frac{d}{a}\right) \times 2.2 \times \sqrt[3]{f_{c}^{\prime} \rho \frac{d}{a}} \times b \times d \quad \lambda<2.5$

Where, $f_{c}^{\prime}$ is the compressive strength of the concrete cylinder; $\rho$ is the longitudinal reinforcement ratio; $d$ is the effective height of the calculated section; $a$ is the distance from the point of concentrated load to the edge of the support section or node; $b$ is the width of calculated section ; $\lambda$ is the shear-span ratio.

\subsection{Comparison of calculation formulas}

In order to analyze the reasonableness of each formula, the ratio of the experimental value of shear bearing capacity of the specimen to the calculated value of each formula is summarized using the collected experimental data, as shown in Table 2.
The shear-span ratio has a large effect on the shear bearing capacity of structure, and studies have shown that the failure pattern of simply supported beams depends largely on the shear-span ratio2.

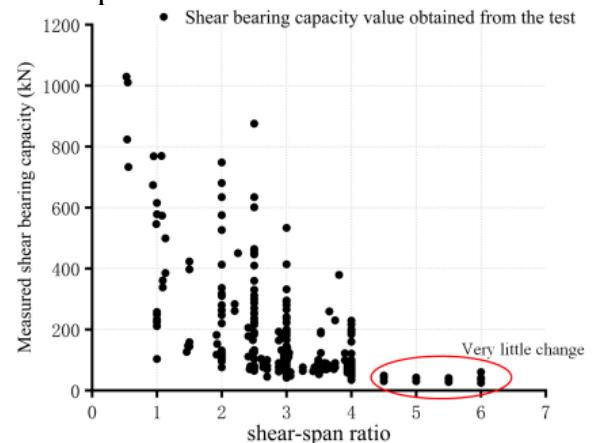

Figure 1. The influence of shear span ratio on the measured shear capacity 
From the distribution of shear bearing capacity data points of 303 pieces of specimens measured in Figure 1, it can be seen that the measured shear bearing capacity value gradually decreases with the increase of shear-span ratio, which is consistent with the results of literature 2 . When the shear-span ratio is less than 1 , the member tends to occur diagonal compression damage, when the shear-span ratio is greater than 4 , the structure tends to occur diagonal tensile damage, combing the collected experimental data, it is found that the measured shear bearing capacity of the structure with diagonal compression damage is much greater than that of the structure with diagonal tensile damage, which indicates that the shear-span ratio is an important influencing factor affecting the shear bearing capacity of HSC beams without web reinforcement. At the same time, it is found that when the shear-span ratio is greater than 4, the shear bearing capacity of HSC beams without web reinforcement is basically little changed.

\subsection{Influence of concrete strength}

Experimental studies have been conducted to show that the strength of concrete has an important effect on the shear bearing capacity of structure, and the shear bearing capacity of ordinary concrete increases with the increase of concrete strength grade. Wang 27 proposed that the nominal shear stress value of concrete beams without web reinforcement under concentrated loads increases with the increase of concrete cubic compressive strength $f_{c u}$, but the relationship between the two is nonlinear. To investigate whether the nominal shear stress of HSC beams without web reinforcement has a linear relationship with the compressive strength of the concrete cube, 116 pieces of experimental data with shear-span ratios ranging from 1 to 3 and longitudinal reinforcement ratios of $1 \%$ to $2.5 \%$ are selected and plotted in Figure 2 in this paper.

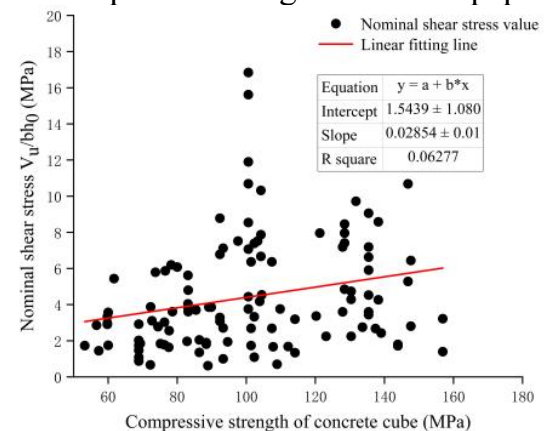

Figure 2. The influence of concrete cube compressive strength on the nominal shear stress of structure

As can be seen from Figure 2 after fitting the data, the slope of the linear equation is only 0.02 , and the $\mathrm{R}^{2}$ (It means the fitting effect, if the value close to 1 , the better.) is too small, the degree of dispersion is serious, and the data points deviate from the fitted straight line more, so the compressive strength of concrete cube of HSC without web reinforcement beams and the nominal shear stress of the structure basically do not constitute a linear relationship. Meanwhile, it can be seen from Figure 2 that the nominal shear stress of the specimen has a tendency to increase gradually as the concrete strength increases.

\subsection{The influence of longitudinal reinforcement ratio}

Longitudinal reinforcement can withstand a certain shear force in the shear process of the cross section, which can inhibit the development of diagonal cracks and increase the shear transfer between the interaction surfaces of diagonal cracks, and increasing the amount of longitudinal reinforcement can increase the height of the concrete shear compression zone, thus indirectly improving the shear bearing capacity of the beams. The shear bearing capacity of the structure increases with the increase of the longitudinal reinforcement ratio, but it is not always significantly increased. Zhang et al. 28 pointed out through their study that when the longitudinal reinforcement ratio is larger, the increase of the shear bearing capacity with the increase of the longitudinal reinforcement ratio is relatively small. In order to study the effect of different longitudinal reinforcement ratios on the shear performance of the structure, all the data are divided into three categories according to the different longitudinal reinforcement ratios $(\rho \leq 1 \%, 1 \%<\rho<2.5 \%$, $\rho \geq 2.5 \%)$, and the nominal shear stress $\left(V_{u} / b h_{0}\right)$ is plotted as the vertical axis and different longitudinal reinforcement ratios as the horizontal axis in Figure 3.

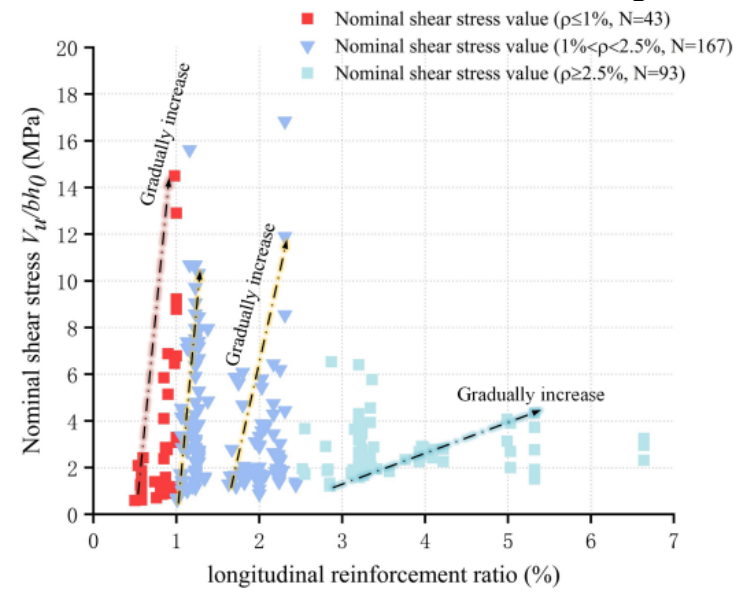

Figure 3. The influence of different longitudinal reinforcement ratios on the shear bearing capacity

Because the strength of concrete and the range of shear-span ratio variables are not limited, which lead the figure 3 data are more discrete, but as a whole, the nominal shear stress of concrete increases gradually with the increase of longitudinal reinforcement ratio, especially the increase is larger when the shear-span ratio is smaller.

\subsection{Influence of section size}

For simply supported beams without web reinforcement, as the section height increases, the width of the diagonal cracks increases, the bite of the aggregate between the cracks decreases, and the shear force transmitted over the cracks decreases. To investigate the effect of size effects on the shear stress in HSC beams web reinforcement, all data are divided into three categories according to the shear-span ratio $(\lambda<1,1 \leq \lambda \leq 3, \lambda>3)$. The nominal shear stress of the structure is used as the vertical axis and 
the effective height of the specimen at different sections as the horizontal axis plotted in Figure 4.

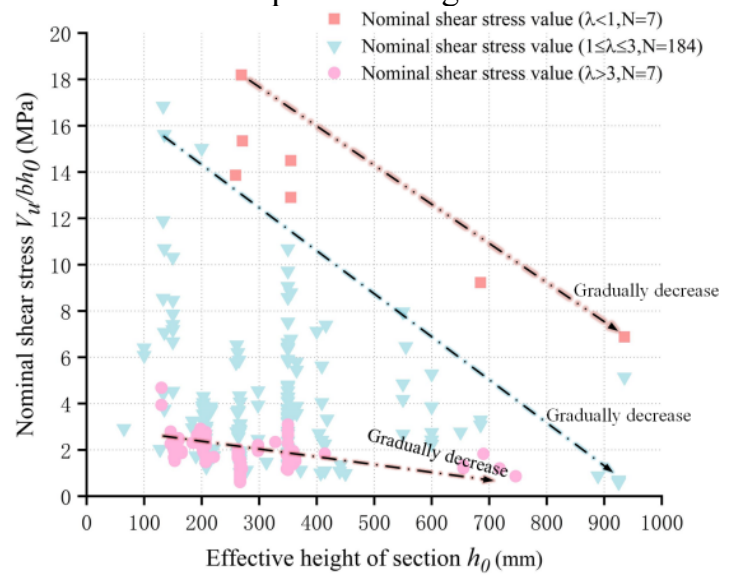

Figure 4. Influence of section size on shear stress of structure

As can be seen from Figure 4, overall, the nominal shear stress of HSC beams without web reinforcement decreases gradually as the effective height of the crosssection increases, and the decrease is greatest for structure with shear-span ratio less than 1 and relatively more moderate for those with shear-span ratio greater than 3 .

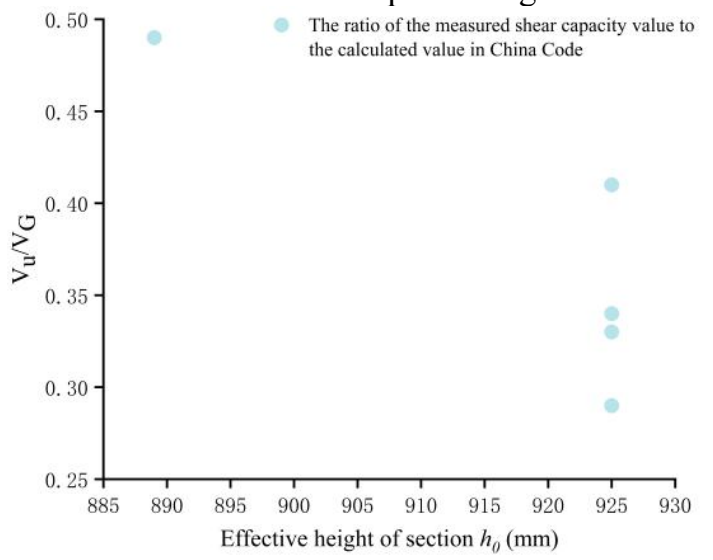

Figure 5. Schematic diagram of the ratio of the measured shear capacity value of the structure under different section heights to the calculated value of the China Code

Figure 5 is a schematic diagram of the ratio between the measured shear bearing capacity and the bearing capacity calculated by the China Code when the effective height of the cross-section of the structure is above $889 \mathrm{~mm}$. It can be seen from the figure that when the effective height of the cross-section is too large, the actual bearing capacity is far from the predetermined design target requirements, resulting in the design is unsafe.

Table3. Comparison of calculation results between the formula proposed in this paper and other formulas

\begin{tabular}{cccccc}
\hline $\begin{array}{c}\text { Number } \\
(\mathrm{N})\end{array}$ & Formula category & Average value & Variance & $\begin{array}{c}\text { Standard } \\
\text { deviation }\end{array}$ & $\begin{array}{c}\text { Coefficient of } \\
\text { variation }\end{array}$ \\
\hline 303 & GB 50010-2010 & 1.551 & 0.88 & 0.94 & 0.61 \\
303 & Zsutty & 1.547 & 0.8 & 0.89 & 0.58 \\
303 & ACI 318 -14 & 2.109 & 2.33 & 1.53 & 0.73 \\
303 & suggested formula & 1.345 & 0.71 & 0.84 & 0.63 \\
\hline
\end{tabular}

It can be seen from Table 3 that the average value of the ratio of the measured shear bearing capacity to the formula proposed in this paper is 1.345 , which has sufficient strength reserve and the fluctuation of each result is small as can be seen from Figure 6. The

\section{Suggested formula}

At present, the engineering does not require accurate calculation of the actual shear bearing capacity of the structure, but requires that it has sufficient safety reserve and will not easily occur shear damage. Although the researches on HSC continues to deepen, there is no unified international result for the calculation formula of shear bearing capacity of HSC beams without web reinforcement, and this paper introduces the Shear Influencing Parameter (SIP) based on the previous discussion using all experimental data and referring to literature 26 to comprehensively consider the effect of concrete strength, shear-span ratio, and longitudinal reinforcement ratio on the shear bearing capacity of the structure, and after statistical regression, a calculation formula for the shear bearing capacity of HSC beams without web reinforcement is proposed :

$V_{c}=31(\mathrm{SIP})^{0.72} b h_{0}$

Among them,

$$
S I P=\left(\frac{f_{t}}{\lambda}\right) \rho
$$

, SIP is defined as the shear influence parameter.

Figure 6 shows the result of a curve fitting on 303 sets of data through software.

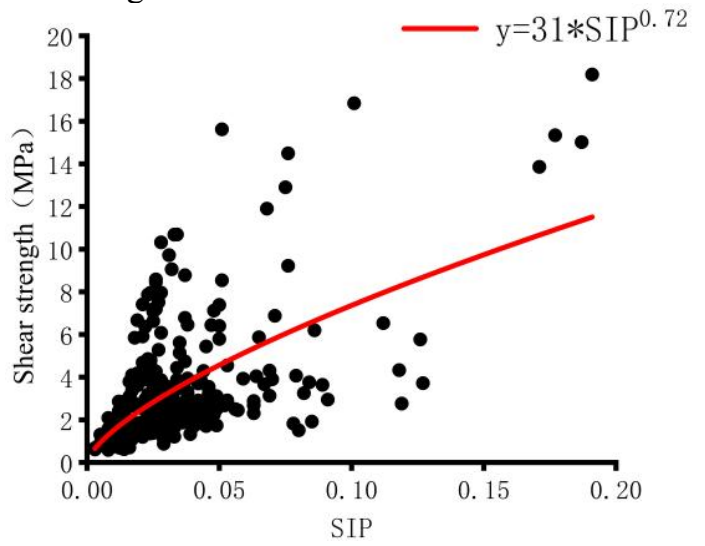

Figure 6. The influence of shear influence parameter on the shear strength of structure

In order to verify the accuracy of the above formula, the formula is brought into the original data for calculation, and the analysis result is compared with the other three formulas, and the results are shown in Table 3: coefficient of variation of the formula proposed in this paper is slightly larger than the result of the China Code calculation, from the data analysis, the main dispersion is shown in the longitudinal reinforcement ratio of $5.52 \%$ of the specimen, these specimens in order to shear damage 
before the occurrence of bending damage and thus the configuration of excessive amount of longitudinal reinforcement, which is not consistent with the common situation of the actual project 28 , but this directly leads to the formula final calculation coefficient of variation is large. In general, the formula proposed in this paper takes into account the influence of the longitudinal reinforcement ratio, which is not much different from the China Code, and even some of the calculated results have little deviation from the measured shear capacity than the China Code, which is suitable for calculating the normal longitudinal reinforcement ratio range of structure.

\section{Conclusion}

Based on the collected experimental data, this paper analyzes the main influence factors and change rules of the shear performance of HSC beams without web reinforcement under concentrated loads, and discusses the calculation method of the shear bearing capacity of HSC beams without web reinforcement under concentrated loads. Based on experiments data and considering the effect of longitudinal reinforcement ratio on the bearing capacity of structure, a new formula for calculation the shear bearing capacity of HSC beams without web reinforcement under concentrated loads is obtained by statistical regression. The conclusions are as follows.

(1) For structure with effective section height of $889 \mathrm{~mm}$ or more, when using the formula suggested by the China Code to calculate, the ratio of the measured value to the calculated value is only $0.29 \sim 0.49$, and the safety reserve is far from enough that should be avoided or other effective measures should be adopted to ensure the shear safety of the structure in practical application.

(2)The measured shear bearing capacity value of HSC beams without web reinforcement gradually decreases with the increase of the shear-span ratio. When the shearspan ratio is greater than 4 , the shear bearing capacity value of the HSC beams without web reinforcement changes little. The nominal shear stress increases with the increase of concrete strength. However, the cubic compressive strength of HSC beams without web reinforcement and the nominal shear stress of structure basically do not constitute a linear relationship. In the lower reinforcement range, the nominal shear stress of HSC beams without web reinforcement increases with the longitudinal reinforcement ratio. When the shear-span ratio is less than 1 , the nominal shear stress of HSC beams without web reinforcement decreases with the increase of the effective height of the section, regardless of the shearspan ratio, when the shear span ratio is less than 1 , the shear stress decreases the most.

(3)Among the formulas for the shear bearing capacity of concrete beams proposed by the China Code, the American Code, and Zsutty, in terms of deviation and accuracy, the formula proposed by Zsutty is more accurate, the formula proposed by American Code is more discrete, and the formula proposed by China Code is between the two. Within the range of normal reinforcement and section height, the overall safety reserve of the three calculation formulas can meet the shear safety requirements.
(4)By constructing the SIP, comprehensively considering the influence of shear-span ratio, concrete strength, and longitudinal reinforcement ratio on the shear bearing capacity of structure, a suggested formula for the shear bearing capacity of HSC beams without web reinforcement is obtained through statistical regression, which is in good agreement with the experimental data, the consideration factors are more comprehensive, and the calculation results are more reasonable.

\section{Acknowledgments}

This research did not receive any financial support, but I would like to thank Prof. Qingfu Li for his careful revision of this paper and encouraging its publication.

\section{References}

1. Ye X G, Wang C C and Zhong X 2012 Experimental study on the shear resistance of HRBF500 reinforced C100 concrete beams Industrial Construction vol 42 pp 86-90 (in Chinese)

2. Bukhari I A and AHMAD S 2008 Evaluation of shear strength of high-strength concrete beams without stirrups Arabian Journal for Science and Engineering vol 33 pp 321-36

3. Cladera A and Mari A R 2005 Experimental study on high-strength concrete beams failing in shear Eng. Struct. vol 27 pp 1519-27

4. Ahmad S H, Khaloo A R and Poveda A 1986 Shear Capacity of Reinforced Concrete Beams ACI Journal, Proceedings vol 82 pp 297-305

5. Elzanaty A H, Nilson A H and Slate F O 1986 Shear capacity of reinforced concrete beams using highstrength concrete ACI Journal, Proceedings vol 83 pp 290-96

6. Yu W J 2012 Research on shear resistance of highstrength concrete beams without web reinforcement Master Thesis Hefei: Hefei University of Technology (in Chinese)

7. Zhi Y F, Wang G F and Li L R 2005 Testing study on the shearing strength of beams of super-strong steelconcrete under concentrated loads Journal of Chongqing University of Technology(Natural Science) vol 19 pp 69-75 (in Chinese)

8. Ye J S 2018 Principles of Structural Design Beijing: People's Communications Press (in Chinese)

9. Wu P M 2003 Concrete structure Wuhan: Wuhan University of Technology Press (in Chinese)

10. Li X 2002 Experimental study on the shear strength of ultra-high-strength concrete beams without web reinforcement under concentrated loads Master Thesis Chongqing: Chongqing University (in Chinese)

11. Wang W L, Xing F and Cao Z L 2006 Experimental study on failure of oblique section of ultra-high strength beams without web reinforcement Journal of 
Shenzhen University(Science and Engineering) vol 23 pp 189-94 (in Chinese)

12. Wang W L, Wang X F and Ding X B 2012 The effect of concrete super-high strengthening on the shear resistance of beams without web reinforcement Journal of Shenzhen University (Science and Technology Edition) vol 29 pp 136-41 (in Chinese)

13. Lv Y M 2008 Experimental research and theoretical analysis of the shear performance of high-strength stirrup and high-strength concrete beams Master Thesis Hunan: Hunan University (in Chinese)

14. Zhao G Y, Wu P G and Zhao C W 1991 Shear strength of high-strength concrete flexural members China Civil Engineering Journal vol 24 pp 10-18 (in Chinese)

15. Pan B R 2009 Experimental study on the shear performance of high-strength concrete beams Master Thesis Hunan: Hunan University (in Chinese)

16. Yang K H, Chung H S and Lee E T 2003 Shear characteristics of high-strength concrete deep beams without shear reinforcements Eng. Struct. vol 25 pp 1343-52

17. Islam M S, Pam H J and Kwan A K H 1998 Shear Capacity of High-strength Concrete Beams with Their Point of Inflection Within the Shear Span Proceedings of the Institution of Civil Engineers Structures and Buildings vol $128 \mathrm{pp}$ 91-9

18. Zhang J W, Zhang D L and Feng C J 2020 Shear test research on HRB600 reinforced high-strength concrete beams without web reinforcement Engineering Mechanics vol 37 pp 275-81 (in Chinese)

19. Ahamad S H, Xie Y and Yu T 1994 Shear strength of reinforced lightweight concrete beams of normal and high strength concrete Mag. Concrete. Res. vol 46 pp 57-66.

20. Suzuki M, Akiyama M and Wang W L 2003 Shear strength of RC beams without stirrup using highstrength concrete of compressive strength ranging to $130 \mathrm{MPa}$ Proceedings of JSCE vol 739 pp 75-91

21. Hamrat M, Boulekbache B and Chemrouk M 2010 Shear Behaviour of RC Beams Without Stirrups Made of Normal Strength and High Strength Concretes Adv. Struct. Eng. vol 13 pp 29-42

22. Jin L Z, Zhou J Land Jiang C S 2017 Experimental performance study on shear capacity of high-strength steel fiber RPC simply supported beams Railway Standard Design vol 61 pp 107-11 (in Chinese)

23. GB50010-2010 2010 Code for Design of Concrete Structures Beijing: China Architecture and Building Press

24. ACI Committee 3182014 Building code requirements for structural concrete (ACI318-14) and commentary American Concrete Institute

25. Zsutty T C 1968 Beam Shear Strength Prediction by Analysis of Existing Data ACI Journal Proceedings vol 65 pp 943-51.

26. Reddy L S, Ramana N V and Gunneswara T D 2010 Shear resistance of high strength concrete beams without shear reinforcement International Journal of Civil and Structural Engineering vol 1 pp 101-13

27. Wang T C and Kang G Y 2001 Shear capacity design of oblique section of high-strength concrete members Journal of Tianjin University(Science and Technology) vol 34 pp 659-63 (in Chinese)

28. Zhang C, Chen C and Zhang B S 2003 The effect of longitudinal reinforcement ratio on the shear behavior of reinforced concrete beams without web reinforcement under concentrated load Journal of Chongqing Jianzhu University vol 25 pp 33-8 (in Chinese) 